\title{
PIRACY IN RUSSIA AND CHINA: A DIFFERENT U.S. REACTION
}

\author{
CONNIE NEIGEL*
}

I

\section{INTRODUCTION}

The development of copyright law in Russia and China is similar in several respects. Both countries developed their copyright laws much later than did Western Europe. Both countries refused to adopt international copyright agreements until pressured by other members of the international community, particularly the United States. Both countries refused adequately to protect foreign works. Despite these similarities, however, Russia and China have experienced very different treatment from the United States when U.S. copyrights have been violated. On the one hand, the United States has aggressively pursued trade sanctions against China to force it to adopt stricter intellectual property laws. With Russia, on the other hand, the United States has adopted a much milder approach and has not threatened trade remedies, despite the widespread piracy of U.S. works in Russia. In general, the United States has appeared to pursue different political, economic, and military goals in its relationships with Russia and China. For example, the United States supported the Russian government after the collapse of the Soviet Union and sought to strengthen the Russian economy, rather than possibly weakening it with threats of trade sanctions. In contrast, the United States threatened trade sanctions against China in an attempt to reduce the U.S. trade imbalance with China. In addition, U.S. policy toward China has been influenced by events in Tiananmen Square and other human rights abuses as well as China's policy of exporting arms and nuclear technology to Third World countries. By contrast, the United States has sought to maintain good relations with Russia to influence its policies of disarmament and nuclear non-proliferation. Finally, the United States has attacked piracy more aggressively in China because China exports its pirated works from the United States into Western markets, resulting in the direct competition of these low-cost, pirated works with legitimate U.S. works. For all of these reasons, the United States has pursued China's copyright abuses more aggressively than it has pursued similar abuses by Russia. This article attempts to explain the reasons for this disparate treatment.

Copyright (C) 2001 by Connie Neigel

This article is also available at http://www.law.duke.edu/journals/63LCPNeigel.

* J.D., 2000, Duke University School of Law. 
This article supplements the treatment of intellectual property law in Law and Contemporary Problems, including the Spring 1996 issue on the Lanham Act. Part II of this article traces the indigenous historical development of Russia's copyright system during the era of tsarist rule in Russia up to the Soviet era and explores more recent responses to external pressures from other members of the international community, in particular the United States. In similar fashion, Part III traces the historical development of China's copyright system, indigenously as well as in response to U.S. trade pressures. Part IV then examines the U.S. response to piracy in Russia and China and attempts to explain the disparate treatment.

\section{II}

\section{HISTORY OF RUSSIA’S COPYRIGHT LAW}

Although Russia developed its first copyright law in the early nineteenth century, it did not adhere to international copyright agreements until almost 150 years later, when external pressures forced the then-Soviet Union to adapt its laws to more stringent international norms.

\section{A. Indigenous Development of Russia's Copyright Law}

Russia produced many of the great composers and authors of the world, but it lagged behind Western Europe in its development of copyright law by almost a century. ${ }^{1}$ Western European countries published books in Slavic languagesand even used the Cyrillic alphabet-soon after the invention of the printing press in 1476, but Russia did not publish its first known book until 1564, almost a century later. ${ }^{2}$ Despite its late development, Russia's copyright law followed a similar path to the laws of Western Europe in the early years. Like its European counterparts, the Russian monarchy sought to control the dissemination of information by controlling printing. ${ }^{3}$ The Russian government regulated the domestic creation of works and the importation of foreign works with the goal of maintaining the state's authority. ${ }^{4}$ For example, between the time of the reign of Ivan the Terrible and Peter the Great's accession to the throne, print-

1. Russia's first copyright law was enacted in 1828. See infra note 10 and accompanying text. England's first copyright law, the Statute of Queen Anne, was enacted in 1709 and is widely considered to be the first law on authors' rights. See EdWARd W. Ploman \& L. Clark HAMilton, Copyright: INTELLECTUAL PROPERTY IN THE INFORMATION AGE 12 (1980).

2. See Michael A. NewCity, Copyright LAw In THE SOVIET Union 4 (1978) (tracing the development of copyright law in Russia from tsarist Russia through the Soviet era) [hereinafter NEWCITY, COPYRIGHT LAW]. The first known book published in Russia was ACTS OF THE APOSTLES AND Messages of the Blessed Apostle Paul. See id.

3. The early history of intellectual property laws in Europe developed out of a similar desire of the state to control the spread of information. See Ploman \& Hamilton, supra note 1, at 9 (noting that the interest and subsequent intervention of governments in the trade of printed materials was motivated by three principal concerns: the spread of knowledge, control, and greed).

4. See NeWCITY, COPYRIGHT LAW, supra note 2, at 4. 
ing was reserved almost exclusively for religious works. ${ }^{5}$ During his reign, Peter considerably loosened the restrictions on printing to permit-and indeed to encourage - the printing of books on secular subjects, including science, education, and culture. ${ }^{6}$ In a dramatic shift from earlier monarchs, Peter encouraged the importation and translation of foreign works. ${ }^{7}$ Subsequent monarchs (except for Catherine during the early part of her reign before the French Revolution) reversed many of Peter's liberal gains, and the state again strictly controlled printing: Unrestricted printers were closed, foreign works were prohibited, and censors controlled the subject matter of books. ${ }^{8}$

During this period in Russia, from the publication of the first known book in the late 1500 s until the mid $1820 \mathrm{~s}$, the numbers of private printers and books increased significantly. ' With more publishers came more opportunities for pirating works. In response to the threat of piracy, Russia enacted its first copyright law, the Censorship Code and Statements on the Rights of the Writer of 1828 ("Copyright Law of 1828"), to prevent the unauthorized publication and distribution of works. ${ }^{10}$ Notably, Russian publishers were free to publish foreign works, either in the original language or in Russian translation. ${ }^{11}$ After its enactment, several changes were made to the Copyright Law of $1828 .^{12}$ The most significant change for foreign authors came in 1857 when the Council of State extended copyright protection to foreign authors who first published their works in Russia. ${ }^{13}$ After undergoing several amendments, the Copyright Law of 1828 was overhauled when a government-appointed commission drafted the new 1911 Copyright Act. ${ }^{14}$ Foreign authors did gain some rights in the 1911 Act: Even though foreign works first published abroad were in the public domain and could be freely translated into Russian, they could not be published in their original languages in Russia without the authors' consent. ${ }^{15}$ According to one commentator, the 1911 Act "can be considered the corner-stone of the devel-

5. During the seventeenth century, 483 books were printed in Moscow, and only seven were nonreligious works. See id.

6. During Peter's reign from 1708 until 1725, more books were published than in the preceding 150 years. See id. at 5 .

7. Not much later, however, in 1771, Russian printers were permitted to reproduce foreign works. Even then, Russian censors screened the foreign works. See id.

8. See id. at 5-6.

9. See id. at 6.

10. See id. at 6-7.

11. See id. at 7-8.

12. In 1830, the Council of State issued a decree that permitted authors to assign and transfer their works. In 1857, the Council of State extended the length of a copyright from life of the author plus 25 years to life of the author plus 50 years. In 1887, almost 50 years after its enactment, the copyright law was separated from the censorship statute and placed in the law of property. See id.

13. See id. at 7.

14. See id. at 8-10 (describing the development and structure of the 1911 act); see also Bernie R. Burrus, The Soviet Law of Inventions and Copyright, 30 FORDHAM L. REV. 693, 711-13 (1962) (summarizing the development of copyright law in Russia and the Soviet Union). The 1911 copyright law was modeled on the German copyright law of 1901. See NEWCITY, COPYRIGHT LAW, supra note 2, at 7.

15. See NEWCITY, COPYRIGHT LAW, supra note 2, at 9. 
opment of copyright legislation under the imperial regime." ${ }^{\prime 16}$ As such, it represented the last change to Russia's copyright regime under imperial Russia. The Bolshevik Revolution and the rise of Leninism ushered in many changes, and copyright law was not immune from its influence.

In the years immediately following the Bolshevik Revolution, the new Soviet government sought to eradicate market influences and launched a program of nationalization and monopolization of property, including intellectual property. To accomplish its objectives, the Soviet government issued several copyright decrees whose purpose was to nationalize the Russian classics, monopolize publishing rights and the publishing industry, establish remuneration schedules for authors of published works, and abolish copyright protection after the death of the author. ${ }^{17}$ The confiscatory approach of the early Soviet years was shortlived. Under Vladimir Lenin's New Economic Policy of 1921, the government sought to encourage private enterprise. ${ }^{18}$ As part of its efforts, the government enacted its first copyright law in 1925 and later amended it in $1928 .^{19}$ Significantly, both laws retained the state's authority to nationalize the works of any author without his consent and denied protection to foreign authors unless they first published their works in the Soviet Union. ${ }^{20}$ The copyright law remained largely unchanged for the next thirty years, and Russians complained that the statute lagged behind technological developments and, in fact, hindered technological progress. ${ }^{21}$ In response, the Soviet government enacted the Fundamentals of Civil Legislation, which, for the first time, sought to integrate copyright law into the civil code. ${ }^{22}$

During this period of the Soviet era, from its inception until the 1960s, the Soviet Union was largely isolationist in its views toward international intellectual property agreements. When its economic interests were at stake, however, the Soviet Union later joined the Universal Copyright Convention ("UCC") and modified its copyright laws accordingly. The next section describes the international influence on Soviet copyright law and looks back to the international influence on earlier copyright law under tsarist Russia.

16. Corien Prins, Computer Program Protection IN THE USSR 118 (1991) (providing an overview of the history of Russian copyright law).

17. See Serge L. Levitsky, Introduction to Soviet Copyright Law, in LAW IN EASTERN EUROPE 31 (Z. Szirmai ed., 1964). Based on the decree of Nov. 26, 1918, the works of many prominent Russian composers were nationalized, including those of Tchaikovsky and Mussorgsky. See id. at 32.

18. See Michael Newcity, Russian Intellectual Property Reform: Towards a Market Paradigm, 36 GERMAN Y.B. INT'L L. 328, 330 (1993) [hereinafter Newcity, Russian Intellectual Property Reform].

19. See PRINS, supra note 16, at 122-24. As fundamentals of copyright law, the 1925 and 1928 laws served as the basis for subsequent copyright legislation in the republics. See id.

20. See NEWCITY, COPYRIGHT LAW, supra note 2, at 22-23.

21. See PRINS, supra note 16 , at 124.

22. See Fundamental Principles of Civil Legislation of the U.S.S.R. and Union Republics (1961), reprinted in SOVIET CODES OF LAW 511 (William B. Simons ed., 1980). For a description of the Soviet copyright law embodied in the civil code, see OLIMPIAD S. IOFFE, SOVIET CIVIL LAW 325-41 (1988). 
B. Development of Russia's Copyright Law in Response to External Pressures

At least as early as 1732 , Russia recognized the significance of international copyright protection. During that year, the Russian monarch Anna Ioannovna forbade the importation of works that had been created in Russia but then republished abroad. ${ }^{23}$ Although issuing state edicts had been a common method of protecting copyrighted works during the eighteenth century, during the nineteenth century, countries turned to bilateral copyright agreements to protect their works. ${ }^{24}$ Russia signed its first bilateral copyright agreement with France in 1861 and signed an agreement with Belgium one year later. ${ }^{25}$ This method of international copyright protection lasted through much of the nineteenth century. Countries later adopted a multilateral approach, and many signed the landmark Berne Convention in $1886 .^{26}$ Russia, however, refused to sign the Berne Convention for three principal reasons. First, and most important, signing the Convention would result in huge costs to the Russian government. Because Russia was a prolific consumer of foreign literature, it would have been obligated to pay royalties to Convention members. ${ }^{27}$ Second, the Russian government regarded the Convention as a device to protect the interests of publishers while ignoring the interests of authors and greater society. ${ }^{28}$ Finally, adherence to the Convention would have forced the Russian government to abolish its policy of free translation. The Russian government relied on freedom of translation to disseminate creative works to its multilingual population. ${ }^{29}$ Instead of signing the Berne Convention, Russia maintained its strategy of negotiating bilateral agreements. ${ }^{30}$

Those bilateral agreements either ended on their own or were rescinded by the Soviet government after the Bolshevik Revolution. During the first decades after the Revolution, the Soviet government was strictly isolationist and repudiated international copyright agreements because it believed that the international agreements served the capitalistic publishers at the expense of the authors. In reality, the Soviet Union likely refused to join the Berne Convention and the subsequent UCC for the same reasons that tsarist Russia had refused: The government did not want to pay huge royalties to foreign authors, and it valued the freedom of translation, which allowed the government to disseminate its message to its multilingual constituency. ${ }^{31}$

23. See M.M. BOGUSLAVSKY, COPYRIGHT IN INTERNATIONAL RELATIONS: INTERNATIONAL PROTECTION OF LITERARY AND SCIENTIFIC WORKS 66 (David Catterns ed., N. Poulet trans., 1979).

24. See NEWCITY, COPYRIGHT LAW, supra note 2, at 10-11.

25. See BOGUSLAVSKY, supra note 23, at 67-73.

26. See Berne Convention for the Protection of Literary and Artistic Works, Sept. 9, 1886, 828 U.N.T.S. 221.

27. See PRINS, supra note 16 , at 119 .

28. See id.

29. See id. at 120.

30. See BoguSLAVSKY, supra note 23, at 68-70. Russia signed another bilateral agreement with France in 1911, with Germany in 1913, with Belgium in 1915, and with Denmark in 1915. See id.

31. See NEWCITY, supra note 2, at 32-33. 
Even during its years of isolation, the Soviet Union recognized the need for Western assistance in its efforts to industrialize. This need for Western technology ultimately would lead the Soviet Union out of isolation and into the world community of intellectual property protection. Anxious to accelerate the process of industrialization, the Soviet leaders pursued a policy of rapid acquisition of foreign technology, or technology transfer." "While the Bolshevik regime bitterly denounced foreign imperialists ... [it] welcomed capitalist technology, importing foreign technicians to teach them how to do things and imitating Western products, plans and processes." ${ }^{33}$ The Soviet government hired U.S. companies to build facilities in the Soviet Union, including dams and industrial complexes, and sent its engineers to the United States to learn how to operate the facilities. ${ }^{34}$ The Soviet Union also licensed foreign technology, though foreign governments and companies demanded protection for their intellectual property in return. To ensure its continued access to licensed Western technology and to assure foreign owners of intellectual property that their works would be protected, the Soviet Union, for the first time, joined an international intellectual property convention, the Paris Convention for the Protection of Industrial Property. ${ }^{35}$

The Soviet Union next faced pressure from the United States to join the Universal Copyright Convention. During bilateral trade negotiations, the United States negotiated Soviet accession to the UCC in exchange for substantial tax concessions. ${ }^{36}$ The United States was responding to domestic political pressure from authors who lost royalties because their copyrights were not recognized in the Soviet Union. ${ }^{37}$ The Soviets finally agreed and joined the UCC in $1973 .^{38}$ Accession to the UCC required that the Soviet legislature revise its copyright law and abolish its long-lived freedom of translation policy. ${ }^{39}$

32. See SusAn K. SEll, POWER AND IdeAs: NORTh-SOUTh Politics OF InTEllectual PROPERTY AND ANTITRUST 49-50 (1998).

33. Melvin Kranzberg, The Technical Elements in International Technology Transfer: Historical Perspectives, in The Political ECONOMY of InTERnAtional TeChNOlOGy Transfer 31, 35 (John R. McIntyre \& David S. Papp eds., 1986).

34. See SELL, supra note 32, at 49. For example, in 1929, Ford built an automobile factory in Gorky, and the Soviet Union sent its engineers to Detroit to learn Ford's production techniques. See id. "Once the factory began producing Model A Fords under a Russian name, the connection with Ford ended and everybody went home." Kranzberg, supra note 33, at 35.

35. See Paris Convention for the Protection of Industrial Property, Mar. 20, 1983, 21 U.S.T. 1583.

36. For a detailed description of the trade talks, see Newcity, Russian Intellectual Property Reform, supra note 18 , at 331-34.

37. The Soviet Union, on the other hand, argued that U.S. tax laws suppressed Soviet sales and licenses of Soviet technology in the United States. See id. at 331-32.

38. See Universal Copyright Convention, Sept. 6, 1952, 6 U.S.T. 2731, 216 U.N.T.S. 132. Observers in the West feared that the Soviet Union would use the UCC to suppress the writings of dissidents. See Lee Jeffrey Ross, Jr., Soviet Accession to the Universal Copyright Convention: Possible Implications for Future Foreign Publication of Dissidents' Works, 4 GA. J. INT'L \& COMP. L. 404 (1974); Alan Schwartz, Russian Roulette, N.Y. TIMES, Mar. 10, 1973, at 29.

39. See PRINS, supra note 16 , at 130 . To comply with the UCC, the Soviet legislature adopted amendments to its civil code on copyrights in 1973. See Newcity, Russian Intellectual Property Reform, supra note 18 , at 332 . 
Even though the international community applauded the Soviet Union's accession to the intellectual property conventions, problems persisted. ${ }^{40}$ The most significant problem was the inadequate protection of foreign works in the Soviet Union. Foreign authors received the same level of protection in the Soviet Union as Soviet citizens enjoyed; that protection, however, was significantly less than the foreign authors received in their home countries. ${ }^{41}$ For example, the Soviet Union retained the power to compel licensing of foreign works and to exclude certain forms of intellectual property from protection. Computer programs and algorithms, for example, received neither copyright nor patent protection. ${ }^{42}$ The international community, particularly the United States, exerted pressure on the Soviet Union to join the Berne Convention so that foreign authors would receive greater protection in the Soviet Union. ${ }^{43}$

The United States negotiated a bilateral agreement with the Soviet Union in which, among other conditions, the Soviet Union agreed to join the Berne Convention in exchange for the United States' grant of "most-favored nation" trading status. ${ }^{44}$ The agreement was signed by Presidents Bush and Gorbachev in June 1990, but President Bush held up Congressional action on the agreement until Soviet officials agreed to reduce piracy of U.S. films and to enact less restrictive immigration laws. ${ }^{45}$ In response to U.S. pressure, on May 31, 1991, the Soviet Union enacted Chapter IV of the Fundamentals of Civil Legislation, which contained principles for a new copyright law. ${ }^{46}$ Before the Fundamentals

40. During later bilateral negotiations between the United States and the Soviet Union, the U.S. Copyright Office identified several problems with the Soviet copyright laws, including "the failure to protect computer programs and databases adequately under copyright law; the failure to protect sound recordings adequately; incomplete public performance rights; overly broad fair use and personal use exemptions; and inadequate enforcement mechanisms generally." Hearings Before the House Judiciary Subcomm. on Intellectual Property and Judicial Admin., 101st Cong. (1991) (statement of Ralph Oman, Register of Copyrights), reprinted in [New Developments 1987-1991 Transfer Binder] Copyright L. Rep. (CCH) II 20,638 (May 16, 1991).

41. See Newcity, Russian Intellectual Property Reform, supra note 18, at 332.

42. See id.

43. The Berne Convention provided more protection for authors, and the international community hoped that Soviet accession to the Berne Convention would reduce the rampant piracy in the Soviet Union. See Copyright is Everybody's Business, UNESCO COURIER (FRANCE), June 1991, at 48; Herbert Mitgang, Old Copyright Treaty: New Shield for U.S. Artists, N.Y. TIMES, Mar. 10, 1989, at B7.

44. See U.S.S.R.-U.S.: Agreement on Trade Relations, June 1, 1990, 29 I.L.M. 946 (1990). Article VIII of the agreement contains several conditions regarding the future protection of intellectual property between the two countries, including an agreement to protect computer programs and databases under domestic copyright laws and to expand copyright protection to sound recordings. See id. at 95556.

45. The Motion Picture Association of America ("MPAA") and its president Jack Valenti exerted enormous pressure on the Bush administration to delay ratification of the agreement until the Soviets modified their copyright laws better to protect U.S. films from foreign pirates. See Lana C. Fleishman, The Empire Strikes Back: The Influence of the United States Motion Picture Industry on Russian Copyright Law, 26 CORNELL INT'L L.J. 189 (1993) (describing in detail the successful lobbying efforts of the MPAA and the influence of the MPAA on Russia's copyright laws). The MPAA, at that time, estimated that it lost $\$ 1.2$ billion each year to foreign pirates. See id. at 218 .

46. See PRINS, supra note 16, at 134 . Interestingly, Mr. Valenti was still not satisfied with Soviet protection of U.S. films, perhaps in part because state-owned television broadcast two Arnold Schwarzenegger films without permission from the U.S. distributors. See id. at 134-35. 
became effective, however, the Soviet Union collapsed. ${ }^{47}$ After the dissolution of the Soviet Union, the Russian Federation assumed responsibility for the trade agreement in a letter to the U.S. Department of State. ${ }^{48}$ To comply with the trade agreement, Russia enacted a series of intellectual property laws, including a law to protect computer programs and databases ${ }^{49}$ and a law to protect integrated circuit topologies. ${ }^{50}$ Russia then enacted a new, comprehensive copyright law in 1993, On Copyright and Neighboring Rights, ${ }^{51}$ and, two years later, joined the Berne Convention. . $^{2}$

Even though Russia incorporated international copyright norms into its copyright laws and joined both the UCC and the Berne Conventions, the United States remains dissatisfied with Russian efforts to combat its rampant piracy. ${ }^{53}$ Video piracy and software piracy are the leading sources of counter-

47. The United States, as promised, did enact most-favored nation legislation for the Soviet Union. It was short-lived, however, as the Soviet Union collapsed only months later. See Most-Favored-Nation Treatment: Union of Soviet Socialist Republics, Pub. L. No. 102-197, 105 Stat. 1622 (1991).

48. See Russian Federation-United States: Exchange of Notes Concerning the Entry into Force of the Agreement on Trade Relations, June 17, 1991, 31 I.L.M. 790 (1992). Russia also adopted the 1961 Fundamentals of Civil Legislation from the Soviet era pending adoption of the new Russian civil code. See Newcity, Russian Intellectual Property Reform, supra note 18, at 337 and note 23 (citing Resolution of the Supreme Soviet of the Russian Federation, July 14, 1992, On the Regulation of Civil Law Relations in the Period of Realization of Economic Reforms, VEDOMOSTI S'EZDA NARODNYKH DePUTATOV R.F., No. 30 (July 30, 1992), Item 1800). For a discussion of the Russian Federation's decision, see Fratislav Pechota, Russian Federation Reaches Back to 1991 USSR Fundamentals of Civil Law, 3 SEEL; SuRV. E. EUR. L., Aug.-Sept. 1992, at 5.

49. See Computer Software and Database Protection Act, reprinted in 3 BUSINESS AND Commercial LAWs OF Russia § 9.04 (John P. Hupp ed., 1995). For a discussion of the Russian intellectual property legislation, see Peter B. Maggs, New Russian Intellectual Property Legislation, 3 SEEL; SURV. E. EUR. L., Nov. 1992, at 1.

50. See Integrated Circuit Lay-Out Protection Act, reprinted in 3 BUSINESS AND COMMERCIAL LAWS OF RUSSIA $\S 9.05$ (John P. Hupp ed., 1995). For a discussion of the Russian intellectual property legislation, see Maggs, supra note 49, at 1.

51. See RF Copyright Act, reprinted in 3 Business AND COMMERCIAL LAWS OF Russia $\S 9.08$ (John P. Hupp ed., 1995). The new copyright law replaced Chapter IV of the 1961 Fundamentals of Civil Legislation. Even after adopting its new copyright law, Russia has modified it as needed. For example, Russia entered into an agreement-Agreement on Partnership and Cooperation-on June 24, 1994, with the European Union to harmonize its copyright law with the European Union's laws. See Michiel Elst, The Interaction of European Community and Russian Copyright Law: A Matter of Partnership and Cooperation, 22 REV. CENT. \& E. EUR. L. 267, 277-329 (1996) (comparing the copyright regimes in Russia and the European Union and concluding that Russian copyright law substantially converges with the European Union's harmonized copyright law).

52. See News, 26 IIC, INT'L REV. Indus. Prop. \& COPYRIGHT L. 451, 455 (1995).

53. The International Intellectual Property Association ("IIPA"), which represents the motion picture, sound recording, computer software, and publishing industries, estimated that in 1997, piracy of motion pictures in Russia resulted in losses of $\$ 312$ million; software losses were $\$ 400$ million; audio recordings losses were $\$ 165$ million; and book publishing losses were $\$ 45$ million. See Don E. Tomlinson, Intellectual Property in the Digital Age: The Piracy/Counterfeiting Problem and Antipiracy and Anticounterfeiting Measures, CURRENTS: INT'L TRADE L.J. 1, 6 Summer 1999. Even if industry estimates of losses due to piracy are speculative, one need only visit a Moscow market to see collections of software, such as Microsoft Windows 95, sold on compact discs ("CD") for just $\$ 3.30$, a fraction of the cost of even a single item of software. See Sergei Blagov, Media-Russia: Copyright Pirates Run Riot, INTER PRESS SERV., Mar. 7, 1998, available in LEXIS, News Library, INPRES File. Cf. Rosalind M. Parker, Protecting American Television Programming in Russia, China, Taiwan, and Japan, 17 HASTINGS COMM. \& ENT. L.J. 445 (1995) (arguing that U.S. television broadcasters and television program suppliers should not be concerned with Russian piracy because most larger Russian television stations ad- 
feiting in Russia. Nearly all of the videos sold in Russia are pirated. ${ }^{54}$ In the 1990s, industry trade groups estimated that the software piracy rate in Russia exceeded ninety percent. ${ }^{55}$ The primary culprits have been government enterprises,${ }^{56}$ but there are small signs of improvements: President Yeltsin ordered the Presidential Council and State Duma to use only licensed programs. ${ }^{57}$ Additionally, legitimate software sales exceeded one million dollars a month in 1995, and one Microsoft executive commented that "Russia is still a superpower of piracy, but it's getting much better." 58 These examples, however, seem to be the exception, not the rule. ${ }^{59}$ Industry trade groups such as the Business Software Alliance ("BSA") and Software Publishers Association ("SPA") assert that Russia's efforts, while laudable, are inadequate to reduce the levels of piracy. ${ }^{60}$

here to copyright protection, any retransmissions of their programs will necessarily be of lower quality, and scrambling devices can reduce the likelihood of piracy). See generally Tim Kuik, Piracy in Russia: An Epidemic, 20 WhitTIER L. ReV. 831 (1999).

54. See Amy Harmon, Russia Has Begun the Daunting Task of Cracking Down on its Massive "Gray Market" for Intellectual Property, L.A. TIMES, Aug. 19, 1996, at D3. The MPAA estimated that video piracy cost the motion picture industry more than $\$ 300$ million in 1997 . See Will Englund, Modern Pirates Thrive in Russia, BALtimore Sun, Jan. 27, 1998, at 1A. Top Hollywood releases can even be seen on unlicensed videocassettes in Russia before their U.S. premieres. See Russians Back Plan to End Film Piracy, Dallas Morning News, July 23, 1997, at 31A.

55. See Software Trade Groups Target Pirates, NewsBYTES News NeTwORK, Feb. 14, 1995, available in LEXIS, Market Library, PROMT File; Vladimir Mikheyev, Russian Market Should Have No Place for "Pirates," CURRENT DIG. OF POST-SOv. PRESS, Dec. 23, 1992, available in LEXIS, News Library, CDSP File. Pirated CDs of Microsoft's Professional Office Suite, legitimate copies of which sell in the United States for $\$ 600$, are available in Moscow for $\$ 11$. See Intellectual Property Developments, EAST/WEST EXECUTIVE GUIDE, Mar. 1, 1996, available in 1996 WL 8665040. The Moscow Times Business Journal estimated that software piracy decreased from $91 \%$ in 1996 , to $89 \%$ in 1997 , to $64 \%$ in 1998. These figures have not been confirmed by outside sources however. See Russia: Intellectual Property Rights Protection: An Overview, INT'L MKT. INSIGHT REP., Mar. 10, 1999, available in 1999 WL 8686531.

56. See Robert Farish, Russian Piracy in a Sea of Software, InDEP. (LONDON), June 14, 1993, at 15 (discussing the institutionalization of software piracy); Microsoft Battling Russian Software Piracy, ECOTASS, May 25, 1993, at 14, available in 1993 WL 2568045. An extreme example of software piracy in Russia occurred when the scientist who "adapted" copyrighted IBM software to run on Soviet mainframe computers was awarded the USSR State Prize. See Peter B. Maggs, Legal Regulation of the Dissemination of Scientific and Technical Information in the USSR, in SOVIET LAW AND ECONOMY 103, 114 (Olimpiad S. Ioffe \& Mark W. Janis eds., 1986).

57. See Patricia Kranz, Taking on the "Superpower of Piracy," Bus. WK., Dec. 19, 1994, at 116B. A major Russian oil company, Gazprom, recently spent over $\$ 500,000$ on licensed software, but the company remains an oddity in Russia. See id.

58. Id. Microsoft reported that its sales increased by $1000 \%$ in the year between July 1993 and June 1994. See id.

59. According to Yury Ryzkhov, Chairman of the Russian Federation Supreme Soviet's Subcommittee on Science and New Technologies, the Russian logic is as follows: "What point is there in turning off a spigot through which technology and works of art make their way here on their own and almost free of charge at a time when we don't have the money to buy them in the needed quantities on a legal basis?" Mikheyev, supra note 55, at 20. As one Russian software entrepreneur, Boris Nuraliev, explains, "[i]n our market, it's not necessary to explain why or how to use ... Lexicon [a widely used Russian word processor], but you do have to explain why to buy it!" Esther Dyson, Remaking Russia, By Computer, N.Y. TIMES, Oct. 10, 1993, at F27 (describing her visit to Moscow to attend a Software Market Association conference and her interactions with Russian entrepreneurs).

60. See Software Trade Groups Target Pirates, supra note 55. SPA Executive Director Ken Wasch commented that "Russia ... deserve[s] credit for enacting copyright laws that specifically protect computer programs and other software. But the astronomical levels of software piracy in [Russia] illus- 
To attack the problems of piracy in Russia, industry groups lobbied the United States Trade Representative ("USTR") to use Special 301, ${ }^{61}$ a weapon in the United States' trade arsenal that authorizes the USTR to use trade sanctions or otherwise limit market access against a country that inadequately protects U.S. intellectual property rights. ${ }^{62}$ In response, USTR Mickey Kantor made "special mention" of nine countries whose intellectual property protections could be improved, including Russia. ${ }^{63}$ Again, in response to pressure from industry groups, USTR Kantor placed Russia on the Watch List in $1995{ }^{64}$ and USTR Charlene Barshefsky elevated Russia to the Priority Watch List in 1997. ${ }^{65}$ Even though Russia remains on the Priority Watch List, ${ }^{66}$ the United

trate[s] what the SPA has learned in the US and abroad-that the law is just the first step toward legal software use." Id.

61. Special 301 is a provision of the Omnibus Trade and Competitiveness Act of 1988 that authorizes the USTR to use trade sanctions or other limits on market access to retaliate against inadequate protection of intellectual property rights. See 19 U.S.C. $\$ 2101$ (1994). For a detailed explanation of how Special 301 operates, see Kim Newby, The Effectiveness of Special 301 in Creating Long Term Copyright Protection for U.S. Companies Overseas, 21 SYRACUSE J. INT’L L. \& COM. 29 (1995). Under Special 301, the USTR must prepare an annual list of Priority Foreign Countries that deny effective protection of U.S. intellectual property or deny equitable market access to U.S. persons who rely upon intellectual property protection. See 19 U.S.C. $\S \S 2242(a), 2411(d)(3)(C)(i i)(1994)$. Although not required by statute, the USTR also prepares a Priority Watch List and a Watch List to alert offending countries that their practices are being monitored by the USTR. See Newby, supra, at 36. The Priority Foreign Country list contains those countries that have the most onerous or egregious practices that deny protection or equitable market access, countries whose practices have the greatest adverse impact, either actual or potential, on the relevant U.S. products, and countries that are not engaging in good faith negotiations to provide effective protection of intellectual property rights. See 19 U.S.C. § 2242(b)(1) (1994). After the USTR identifies a Priority Foreign Country, the USTR must within 30 days initiate an investigation of the country and its offending practices and must take action if no substantial progress has been taken by the Priority Foreign Country within the period of the investigation. See 19 U.S.C. $\S \S 2412(b)(2)(A), 2411(a)(1)$ (1994). The USTR has broad discretionary authority in deciding what actions to take, but the three main tools include the suspension of trade benefits, the imposition of duties or other import restrictions, and the entering into of binding agreements to stop the offending practices. See 19 U.S.C. § 2411(c)(1) (1994).

62. The IIPA annually identifies to the USTR countries that violate intellectual property rights. In February 1994, the IIPA recommended to USTR Mickey Kantor that Russia be added to the Watch List. See Industry Presses U.S. to Act Against Thirty-six Countries for Copyright "Piracy," 11 Int'l Trade Rep. (BNA) 274 (Feb. 23, 1994).

63. See USTR Announcement and Fact Sheets on Decisions Affecting Foreign Government Procurement, Intellectual Property Protection, and U.S.-Japan Supercomputer Pact, 11 Int'l Trade Rep. (BNA) 722 (May 4, 1994).

64. In February 1995, the IIPA recommended elevating Russia to the Priority Watch List. See China, Turkey, India, Brazil Faulted for Intellectual Property Inaction, 12 Int'l Trade Rep. (BNA) 292 (Feb. 15, 1995). In May 1995, USTR Kantor placed Russia on the Watch List. See USTR Announcement on Foreign Government Procurement (Title VII) and Intellectual Property Protection (Special 301), 12 Int'l Trade Rep. (BNA) 791 (May 3, 1995).

65. In 1997, industries dependent on copyrights, including makers of software, movies, and sound recordings, urged Acting USTR Charlene Barshefsky to threaten trade sanctions against Russia. According to the IIPA, Russia, Greece, and Paraguay were responsible for $\$ 1.29$ billion in losses to U.S. companies as a result of unauthorized copying and sales of movies, music, computer software, and books. See Mark Felsonthal, Copyright, Patent Holders Urge Action Against Argentina, India, Russia, Others, 14 Int'l Trade Rep. (BNA) 292 (Feb. 19, 1997). Later that year, USTR Barshefsky elevated Russia from the Watch List to the Priority Watch List. See USTR Launches WTO Proceedings Against Denmark, Others Over Copyrights, 14 Int'l Trade Rep. (BNA) 812 (May 7, 1997).

66. See Daniel Pruzin, WTO Postpones Seattle Post-Mortem; Will Take No Action on Missed Deadline, Int'l Trade Daily, Dec. 20, 1999 (BNA), available in LEXIS, BNA Library, BNAITD File. 
States has not threatened trade sanctions against Russia, in contrast to its multiple threats against China for similar violations of intellectual property laws. ${ }^{67}$ Part IV of this article compares how the United States has reacted to violations of copyright laws in Russia and China. Before one can consider U.S. reaction to China's copyright violations, it is helpful to understand how copyright law developed indigenously in China and how U.S. trade pressures shaped China's copyright regime. Part III explores the development of China's copyright laws.

III

\section{HISTORY OF CHINA's COPYRIGHT LAW}

China was among the first countries to develop printing, ${ }^{68}$ yet it did not enact its first copyright law until more than one thousand years later. ${ }^{69}$ During the thousand-year interval, China developed a modest system of copyright that accommodated the economic, political, and social conditions of the time. ${ }^{70}$ During the twentieth century, however, external pressures forced China to adapt its laws to more stringent international norms. ${ }^{71}$

\section{A. Indigenous Development of China's Copyright Law}

Before the twentieth century, China had no formal copyright system. ${ }^{72}$ More than one thousand years earlier, however, China had begun to enact rules to control the dissemination of ideas. ${ }^{73}$ Emperors, beginning with the Wenzong Emperor in A.D. 835, prohibited the unauthorized reproduction of items that

67. See discussion infra Part III.B.

68. See William P. Alford, To Steal a Book is an Elegant Offense: Intellectual PROPERTY LAW IN CHINESE CIVILIZATION 1 (1995) [hereinafter ALFORD, TO STEAL A BOOK] (tracing the development of copyright law in China, from the advent of printing during the Tang Dynasty (A.D. 618-906) to modern-day China and examining why copyright law has never taken hold in China as it has in the West). Chinese historians date the advent of printing to the Tang Dynasty (A.D. 618906): China is credited with contributing paper, movable type, and ink to humankind. See id. at 1, 9. Even before the invention of the printing press, the Chinese were interested in preventing the unauthorized reproduction of texts: During the Qin Dynasty (221B.C.-206 B.C.), the rulers were concerned with the distribution of written materials, and during the Han Dynasty (206 B.C.-A.D. 220), the rulers barred the unauthorized reproduction of the Classics. See id. at 12-13.

69. See Zheng Chengsi \& Michael Pendleton, Copyright law in China 17 (1991) (discussing the enactment of China's first official copyright law in 1910 and the enactment of its first copyright law that met international standards in 1990).

70. See William P. Alford, Don't Stop Thinking About ... Yesterday: Why There Was No Indigenous Counterpart to Intellectual Property Law in Imperial China, 7 J. CHINESE L. 3, 7-34 (1993) (describing the development of China's system of copyright through its imperial history).

71. See Julia Cheng, Note, China's Copyright System: Rising to the Spirit of TRIPS Requires an Internal Focus and WTO Membership, 21 FORDHAM INT'L L.J. 1941, 1965-79 (1998) (examining the effect of threatened trade sanctions by the United States on the development and enforcement of China's copyright laws).

72. See Zheng Chengsi \& Michael D. Pendleton, Chinese Intellectual Property and TECHNOLOGY TRANSFER LAW 87 (1987).

73. See Alford, To SteAl A BoOK, supra note 68, at 16-17. The rulers were motivated by a desire to sustain imperial power more than any interest in sharing information with the Chinese people. See id. 
could be used for prognostication. ${ }^{74}$ Subsequent emperors expanded the ban to include heterodox items and materials under the exclusive control of the state, such as the Classics and official government documents. ${ }^{75}$ After the invention of the printing press, production of printed materials increased, and Chinese emperors ordered private printers to submit works to government officials for prepublication review. $^{76}$

China's desire to control the dissemination of information was shared by European governments. The early history of intellectual property laws in Europe developed out of a similar desire of the state to control the spread of information. ${ }^{77}$ European attitudes toward copyright diverged from that of China in the seventeenth and eighteenth centuries, however, when European societies adopted the view that an author had a property right in his work, ${ }^{78}$ a concept that had no counterpart in China. ${ }^{79}$ Europeans believed that society would benefit by providing incentives to create and disseminate works. China, on the other hand, continued to regulate the creation of works, with the goal of maintaining the state's authority. ${ }^{80}$

Finally, in 1910, just one year before the overthrow of the Qing Dynasty (A.D. 1644-1911), the government enacted China's first formal copyright law. ${ }^{81}$ The law provided comprehensive copyright protection. ${ }^{82}$ It was never fully implemented, however, because the Qing government was overthrown by the Northern Warlords government (1912-1927) the following year. ${ }^{83}$ Both the Northern Warlords government and the subsequent Nationalist (Guomindang)

74. See id. at 13. Chinese rulers prohibited the unauthorized reproduction of calendars, almanacs, and other items that could be used for prognostication because rulers sought to control information related to time and astronomy. See id. at 13.

75. See AlFORD, To STEAL A BOOK, supra note 68, at 13 . In addition to items of prognostication, materials subject to exclusive state control included the Classics, state legal pronouncements, official histories, model answers to imperial civil service examinations, maps, and materials concerning the inner workings of the government, politics, and military affairs. See id. at 13-14. Heterodox materials included pornographic materials, politically or religiously suspect materials, and writings that used the names of members or ancestors of the imperial family in inappropriate literary styles. See id. at 14, 2324.

76. See AlFord, To STEAL A BooK, supra note 68, at 13-17. Even though prepublication review started much earlier, the Qianlong Emperor's famous decree of 1774 required all literature to be reviewed so that any books containing heterodox material could be destroyed. See id. at 15.

77. See Ploman \& HAMilton, supra note 1 , at 9.

78. See id. at 11.

79. See AlFORD, To STEAL A BooK, supra note 68, at 18.

80. See id. Economic and technological factors partly explain China's failure to protect authors' creations. See id. at 19. The mechanisms and demand for mass production did not exist in China as they did in Europe. Preindustrial China did not have means of mass production, and the literacy rate was under $20 \%$ even in the early part of the twentieth century. See id.

81. See Chengsi \& Pendleton, Copyright Law in China, supra note 69, at 17.

82. See Amy E. Simpson, Comment, Copyright Law and Software Regulations in the People's Republic of China: Have the Chinese Pirates Affected World Trade, 20 N.C. J. INT'L L. \& COM. REG. 575, 582 (1995) (explaining that the copyright law of 1910 offered extensive protection to works of literature and art, pamphlets, calligraphy, photographs, sculptures, and models).

83. See Chengsi \& Pendleton, Copyright law in China, supra note 69, at 17. 
government (1912-1949) revised the statute in 1915 and 1928, respectively. ${ }^{84}$ But China's copyright law was short-lived.

In 1949, the Communist Party rose to power and overturned all existing copyright and publication laws. ${ }^{85}$ Mao Tse-Tung and the Chinese Communist Party expelled all foreigners and foreign influence from the state. ${ }^{86}$ As part of the Chinese Communist Party's promise of a better life, the government initiated a system of publishing contracts that provided remuneration between authors and publishers. ${ }^{87}$ Even though the publishing contracts provided royalties to authors, the system failed adequately to protect authors' copyrights because the publishing contracts did not control unauthorized reproduction by third parties. ${ }^{88}$ Even this limited system of copyright was short-lived; royalties were significantly reduced in 1958 when Mao Tse-Tung launched the AntiRightist Movement and the Great Leap Forward to accelerate China's transition to socialism. ${ }^{89}$ Later, all royalties were eliminated, and the system of publishing contracts was dismantled when the Cultural Revolution began in $1966 .{ }^{90}$ The Cultural Revolution was a tumultuous period in which most creative intellectual work stopped, and copyright infringement was rampant. ${ }^{91}$

By the end of the Cultural Revolution, China faced a faltering economy and an ineffective and unproductive bureaucratic system. ${ }^{92}$ Instead of producing a better life for the Chinese people, the Communist Party produced unneeded goods while the demands of the Chinese consumers remained unfulfilled. ${ }^{93}$ After Mao Tse-Tung's death in 1976, Deng Xiaoping and his allies adopted an

\section{See id.}

85. See Mark Sidel, Copyright, Trademark, and Patent Law in the People's Republic of China, 21 TEX. INT'L L.J. 259, 261 (1986).

86. See Janiece Marshall, Current Developments in the People's Republic of China: Has China Changed?, 1 TRANSNAT'L LAW. 505, 508 (1988) (explaining that the Chinese Communist Party promised the Chinese people a better life by modernizing the country and rescuing the nation from invasion by imperialistic states).

87. See Sidel, supra note 85, at 261-63. During the 1950s, the General Publishing Office of the Central People's Government issued public resolutions that governed the publishing contracts between authors and publishers. See Yiping Yang, The 1990 Copyright Law of the People's Republic of China, 11 UCLA PAC. BASIN L.J. 260, 263 (1993). The 1950 Publishing Resolution provided a per-word and per-copy royalty system. See Sidel, supra note 85 , at 263 . This system of publishing contracts was later dismantled during the Cultural Revolution. See id.

88. See Sidel, supra note 85, at 262.

89. See id. at 263.

90. See Yang, supra note 87, at 263.

91. See Sidel, supra note 85, at 263. During the ten years of the Cultural Revolution (1966-1976), most creative intellectual work stopped. See id. at 263-64. The Communist Party tortured, killed, and imprisoned many intellectuals; it sent others to work on communes or state farms. See id. at 263. According to official materials published in connection with the trial of the "Gang of Four," 720,000 persons were directly persecuted during the Cultural Revolution, and 34,000 among them were killed. See Albert Hung-YeE CHEN, AN INTRODUCTION TO THE LEGAl SySTEM OF THE PEOPLE's REPUBLIC OF CHINA 30 (1994). Less egregious offenses were also committed: The state government endorsed copyright infringement when it promulgated regulations in 1972 that permitted a publisher to reprint another publisher's work without permission or payment so long as the reprinting publisher noted the name of the original publisher. See Sidel, supra note 85, at 264.

92. See Marshall, supra note 86, at 508.

93. See id. at 509 . 
economic development plan to bring China out of economic isolation and to attract foreign investment, trade, and the transfer of technology. ${ }^{94}$ China "essentially abandoned Marxist economics in favor of a dual system, namely, a oneparty autocratic political system, coupled with a government assisted free market economy." When China adopted its Open Door Policy in the late 1970s, Western nations, primarily the United States, pressured China to enact more protective intellectual property laws. ${ }^{96}$ China responded in 1990 by enacting its Copyright Law of the People's Republic of China ("Copyright Law of the P.R.C."), the first one that met international standards. " China's copyright law granted private rights to authors but maintained a socialist purpose ${ }^{98}$ illustrating China's efforts to adopt a market economy within a socialist governmental framework. ${ }^{99}$

China incorporated international norms into its copyright law, but the law offered limited protection for foreign works. It protected a work by a foreign entity only if the work was first published in China or if it was published in China within thirty days of its initial foreign publication. ${ }^{100}$ The U.S. business

94. See id. at 508-10 (describing Deng Xiaoping's plan to revitalize China's faltering economy by attracting foreign trade and investment). This policy was antithetical to China's previous policies of isolation and exclusion under Mao Tse-Tung. See id. at 509-10. The economic development plan, termed "The Four Modernizations," had four goals: (1) to reform aspects of the political and policymaking system; (2) to revitalize and reform the educational system; (3) to change China's orientation to and role in the global economy; and (4) to alter the nation's demographic trajectory. See id. at 509. The leaders believed that China would never reach a state of economic development equal to that of the Western countries unless it increased its application of modern technology to all sectors of the Chinese economy. See id.

95. Roy J. Girasa, Legal Aspects of Doing Business in China, 20 WESTCHESTER B.J. 305, 305 (1993). For a complete description of the legal reforms in China during the period of reform, see DU XiCHUAN \& ZHANG LiNGYUAN, CHINA’S LEGAL SYSTEM: A GENERAL SURVEY (1990).

96. See Yang, supra note 87, at 260.

97. Copyright Law of the People's Republic of China (1990), THE LAws of THE PEOPLE'S RePUBLIC OF CHINA: 1990-1992, at 75 (Science Press 1993) [hereinafter Copyright Law]. Before enacting the Copyright Law of the P.R.C., the Chinese government issued one of its most important administrative regulations, the 1984 Regulation, which embodied the principle "to each according to his labor," and which was designed to promote intellectual creation by protecting the rights of authors and translators. See Simpson, supra note 82, at 585. The Chinese State Council established the National Copyright Administration of China to write the copyright law. See id. at 586. China's copyright law required twenty drafts and eleven years to complete. See Edward G. Durney, Copyright Law in China and Taiwan, in GlOBAl InTELleCtUAl PrOPERTY SERIES 1993: PROTECTING TRADEMARKS AND COPYRIGHTS; SuCCESSFul STRATEgIES, 311, 315 (PLI Patents, Copyrights, Trademarks, \& Literary Property Course Handbook Series No. 367, 1993).

98. See White Paper: Intellectual Property Protection in China, BRITISH BROADCASTING CORP., June 20, 1994, available in LEXIS, World Library, BBCMIR File (noting that China's stated purpose in developing its intellectual property system was "to rapidly develop social productive forces, promote overall social progress, meet the needs of developing a socialist market economy and expedite China's entry into the world economy"). Article 1 of the Copyright Law of the P.R.C. provides:

This law is formulated in accordance with the Constitution to protect the copyright of authors on their literary, artistic and scientific works as well as rights and interests related to copyright, to encourage the creation and dissemination of works beneficial to the building of a socialist society that is advanced materially as well as culturally and ideologically and to promote the progress and prosperity of socialist culture and science.

Copyright Law, supra note 97 , at 77-78.

99. See Durney, supra note 97 , at 315.

100. See Simpson, supra note 82, at 590-91. 
community strongly disapproved of the original version of the Copyright Law of the P.R.C., and the U.S. government threatened trade sanctions against China, ${ }^{101}$ the first in a series of trade disputes between the United States and China over intellectual property protection. ${ }^{102}$

\section{B. Development of China's Copyright Law in Response to External Pressures}

Even though China substantially incorporated international copyright norms into its copyright law, the U.S. business community lobbied the U.S. Department of Commerce to pressure China to change its law to provide stronger protection for foreign works. ${ }^{103}$ In response to the U.S. business sector's complaints and lobbying efforts, the USTR retaliated against China and invoked Special 301..$^{104}$ Pursuant to Special 301, the USTR placed China on the Priority Foreign Country list and threatened trade sanctions against China unless it provided more protection for U.S. intellectual property works, particularly computer software..$^{105}$

Lengthy negotiations between the United States and China resulted in a comprehensive agreement, the Memorandum of Understanding on the Protection of Intellectual Property, in January 1992 ("1992 MOU"). ${ }^{106}$ The 1992 MOU was signed just two hours before U.S. retaliatory measures were to be implemented. ${ }^{107}$ The 1992 MOU required China to increase its protection of U.S. intellectual property and to join two international copyright conventions-the Berne Convention and the Convention for the Protection of Producers of Phonograms Against Unauthorized Duplication of Their Phonograms ${ }^{108}$ - which

101. See id. at 591.

102. See infra Part III.B (discussing U.S.-China trade disputes over China's lack of enforcement of its copyright laws).

103. See Cheng, supra note 71, at 1967-68. For a detailed description of the lobbying efforts of U.S. industry on the United States Trade Representative, see Paul C.B. Liu, U.S. Industry's Influence on Intellectual Property Negotiations and Special 301 Actions, 13 UCLA PAC. BASIN L.J. 87, 88-93 (1994).

104. For an explanation of Special 301, see supra note 61. See also June Cohan Lazar, Protecting Ideas and Ideals: Copyright Law in the People's Republic of China, 27 LAW \& POL'Y INT'L BUS. 1185, 1188 (1996); Newby, supra note 61, at 36. The United States has recognized that a foreign government's tolerance of piracy may constitute a non-tariff barrier with trade distortion effects. See Y. Kurt Chang, Special 301 and Taiwan: A Case Study of Protecting United States Intellectual Property in Foreign Countries, 15 Nw J. INT'L L. \& BUS. 206, 212 (1994).

105. See Lazar, supra note 104 , at 1188 . After being placed on the list, China agreed to protect computer programs as literary works under the terms of the Berne Convention, and implemented the Computer Software Protection Regulations ("Computer Software Regulations"). See Computer Software Protection Regulations, CHINA L. \& PRAC., Aug. 19, 1991, at 55 (effective Oct. 1, 1991). After the Chinese government issued the Computer Software Regulations in 1991, U.S. businesses remained dissatisfied, and China remained on the Priority Foreign Country list. See Jeffrey K. Parker, Lawyers Wary of China's New Software Protection Rules, UPI, June 14, 1991, available in LEXIS, News Library, UPI File.

106. See U.S.-P.R.C., Memorandum of Understanding on the Protection of Intellectual Property, Jan. 17, 1992, 34 I.L.M. 676 [hereinafter Memorandum].

107. See Newby, supra note 61, at 42.

108. See Memorandum, supra note 106, at $680-81$. 
China joined in 1992 and 1993, respectively. ${ }^{109}$ Pursuant to the 1992 MOU, the United States recognized China's progress and removed it from the Priority Foreign Country List. ${ }^{110}$

Subsequently, the United States became frustrated with the Chinese government's lack of enforcement of its intellectual property laws, and USTR Mickey Kantor again placed China on the Priority Foreign Country list in $1994^{111}$ and threatened Special 301 trade sanctions worth $\$ 1.08$ billion on Chinese products. ${ }^{112}$ The Chinese government retaliated by threatening its own trade sanctions against the United States; the Chinese government was upset that it had diligently modified its copyright system in compliance with U.S. demands, yet the United States had not allowed sufficient time for the system to produce the desired results. ${ }^{113}$

The two countries averted a threatened trade war when they signed a lastminute agreement, China-United States: Agreement Regarding Intellectual Property Rights ("1995 Agreement"). ${ }^{114}$ The 1995 Agreement contained two documents: a letter from the Chinese Minister of Foreign Trade and Economic Cooperation to the USTR ("Agreement Letter") and an Action Plan for Effective Protection and Enforcement of Intellectual Property Rights in China ("Action Plan"). ${ }^{115}$ The 1995 Agreement provided for enhanced enforcement measures by the Chinese and greater access for U.S. intellectual property producers to Chinese markets, particularly the audio-visual sector. ${ }^{116}$

109. See Cheng, supra note 71, at 1968 . To harmonize its laws with the Berne Convention, China promulgated the Implementing International Copyright Treaties Provisions. See Implementing International Copyright Treaties Provisions, ChINA L. \& PRAC., Jan. 14, 1993, at 36 (effective Sept. 30, 1992).

110. See Memorandum, supra note 106, at 683-84. The USTR moved China to the lower-level Watch List, which contained 17 other offending countries. See Newby, supra note 61, at 43.

111. See Newby, supra note 61, at 43.

112. See U.S., China Announce Broad Agreement on Intellectual Property Protection, 12 Int'l Trade Rep. (BNA) 400 (Mar. 1, 1995).

113. See Newby, supra note 61, at 43-44. Li Changxu, head of the China United Intellectual Property Investigation Center, commented, "It's like building a house. You can have the house structure all set up, very beautiful. But then, you need electricity and water pipes. That takes more time." Marcus W. Brauchli \& Joseph Kahn, Intellectual Property: China Moves Against Piracy as U.S. Trade Battle Looms, ASIAN WALL ST. J., Jan. 6, 1995, at 1. China reported progress in its efforts to curb copyright piracy: According to the official Xinhua news agency, in early November 1994, approximately 53,000 laser disks were confiscated and over 100 shops wholesaling illegal audio and video products were closed. See China Reports Efforts on Copyright Piracy, ASIAN WALL ST. J., Jan. 11, 1995, at 4. Despite the Chinese government's efforts, the Business Software Alliance, the industry group representing major U.S. computer software publishers, reported that Chinese software piracy cost the industry $\$ 322$ million in 1994 and that approximately 94 percent of the software in China was pirated. See Software Industry Believes U.S. Will Stay Tough on Piracy, AgenCE France Presse, Jan. 3, 1995, available in LEXIS, News Library, AFP File.

114. See Agreement Regarding Intellectual Property Rights, Feb. 26, 1995, P.R.C.-U.S., 34 I.L.M. 881 (1995) [hereinafter 1995 Agreement].

115. See id.

116. See id. at 882-83. A spokesman for the IIPA referred to the 1995 Agreement "as a real beginning of a crackdown on piracy." See U.S., China Announce Broad Agreement on Intellectual Property Protection, supra note 112, at 400. According to USTR Mickey Kantor, "[o]ur Chinese counterparts have committed themselves to a very impressive set of enforcement procedures here, not only en- 
Despite the optimism surrounding the 1995 Agreement, U.S. officials subsequently charged that China had failed to adequately implement the Action Plan; Chinese officials countered that they had made great strides in reducing copyright infringement. ${ }^{117}$ According to the 1995 Agreement, the Chinese government agreed to crack down on piracy of music, films, and software ${ }^{118}$ and later promised to shut down twenty-nine compact disc ("CD") factories that were the worst offenders. ${ }^{119}$ American investigators found, however, that only one factory remained closed, and production of pirated CDs doubled in China in the ten months following the 1995 Agreement. ${ }^{120}$ For the third time since enacting the Special 301 provisions, the United States placed China on the Priority Foreign Country list. ${ }^{121}$ Within thirty minutes of the announcement by Acting USTR Charlene Barshefsky that the United States had placed China on its Priority Foreign Country list, China published its own retaliation list of U.S. products that would be subject to $100 \%$ tariffs; the list was identical to the U.S. list of Chinese products. ${ }^{122}$ Despite the threats, both countries averted another multibillion-dollar trade war when they reached an agreement hours after a June 17, 1996, deadline. ${ }^{123}$ Acting USTR Barshefsky announced that the United States would withdraw the threat of $\$ 2$ billion trade sanctions because China had taken serious and important steps to combat piracy in recent months, including the closure of fifteen pirate $\mathrm{CD}$ factories and the enlistment of China's

forcement, but market access as well." Id. A key aspect of the settlement was the raiding and closure of seven of twenty-nine factories producing pirated music compact disks and movie laser disks. See id.

117. See Andrew J. McCall, Copyright and Trademark Enforcement in China, 9 TRANSNAT'L LAw. 587, 603-05 (1996).

118. See 1995 Agreement, supra note 114, at 883.

119. See Maggie Farley, Peril Escalates for Team Fighting Piracy of CDs, L.A. TIMES, Dec. 25, 1995, at D4.

120. See Joseph Kahn, China Plans to Cut Tariffs, End Quotas in Bid to Join Trade Group, WALL ST. J., Nov. 20, 1995, at A10 [hereinafter Smith, U.S. Trade Officials Plan to Fault China]. According to U.S. officials, piracy of music and computer software actually increased in the year following the 1995 Agreement. See Craig S. Smith, U.S. Trade Officials Plan to Fault China on its Lax Antipiracy Steps, New Curbs, WAll ST. J., Feb. 7, 1996, at A10. U.S. businesses continued to lose revenues after the 1995 Agreement because the Chinese government failed to curb piracy. According to Steven Ballmer, then-Executive Vice President for Microsoft, China's software market in 1995 was about equal to that of France, yet Microsoft's China revenues were only about three percent of the total for France. See Craig S. Smith, Microsoft Says Pirate Copies Sap China Profits, WALl ST. J., Oct. 27, 1995, available in 1995 WL-WSJ 9905759. The IIPA estimated its 1995 losses to Chinese piracy at $\$ 1.84$ billion, excluding business software, and the Software Publisher's Association estimated business software losses at $\$ 250$ million a year. See Marcus W. Brauchli, China Could Face U.S. Trade Sanctions of Over \$2 Billion Due to Piracy Losses, WAll ST. J., Feb. 26, 1996, at A9.

121. See Rossella Brevetti, USTR Identifies China as Priority Foreign Country, 13 Int'l Trade Rep. (BNA) 704 (May 1, 1996). In previous negotiating sessions, acting USTR Charlene Barshefsky had threatened Chinese officials with $\$ 2$ billion in trade sanctions if China did not make sufficient progress in several areas: closing six factories that produced pirated compact disks and laser disks, increasing market access for U.S. entertainment and publishing firms, and strengthening customs controls. See Robert S. Greenberger, U.S. Sharply Attacks China Over Intellectual Property, WALl ST. J., May 1, 1996, at A3.

122. See Helene Cooper \& Kathy Chen, U.S. and China Announce Tariff Targets as Both Nations Step Up Trade Rhetoric, WALl ST. J., May 16, 1996, at A3.

123. See Kathy Chen, U.S. and China Reach an Agreement, Averting Trade Sanctions by Both Sides, WALl ST. J., June 18, 1996, at A2. 
powerful national police, the Ministry of Public Security, to help combat piracy. ${ }^{124}$ The 1996 Agreement recounted the 1995 Agreement, but U.S. officials expressed optimism that "things will be different this time around." 125

China made significant progress in combating piracy after signing the 1996 Agreement. Chinese authorities closed thirty-nine factories making illegal copies of U.S. music, movies, and business software, and it arrested more than 250 individuals. ${ }^{126}$ Piracy problems persist, however, including widespread computer software piracy. ${ }^{127}$ Moreover, movie piracy is on the rise: Video compact disks of the "Titanic" sold for US\$2 in Shanghai one month before its theatrical release in the United States, and Chinese authorities essentially abandoned their efforts to prevent the sale of illegally copied videodisks. ${ }^{128}$ The United States has vowed to impose trade sanctions should China reduce its efforts to fight piracy of U.S. works. ${ }^{129}$ However, despite the widespread piracy of U.S. software and movies, the United States has not officially threatened trade sanctions since 1996. Chinese piracy of U.S. products remains an area of contention between the United States and China, and the United States is grappling with strategies to combat China's piracy of valuable U.S. intellectual property.

IV

\section{ANALYSIS OF THE U.S. RESPONSE TO PIRACY IN RUSSIA AND CHINA}

The United States reacted aggressively against China when it engaged in widespread piracy and failed to protect U.S. intellectual property. ${ }^{130}$ U.S. reaction toward Russia, however, was comparatively mild. ${ }^{131}$ When China failed adequately to protect U.S. intellectual property, the United States placed China on the Priority Country List under Special 301 and threatened trade sanctions on three separate occasions. In 1991 and 1994, trade sanctions were averted

124. See Statement by Acting USTR Charlene Barshefsky on Trade Talks with China on Intellectual Property Rights and Fact Sheet on Chinese Implementation of 1995 IPR Enforcement Agreement, 13 Int'l Trade Rep. (BNA) 1036, (June 19, 1996) [hereinafter Statement by Acting USTR]; see also Mark Felsenthal, U.S., China Agree on Copyright Shields; \$2 Billion Sanction Threat is Dropped, 13 Int'l Trade Rep. (BNA) 998 (June 19, 1996).

125. Chen, supra note 123 , at A2. U.S. industry officials expressed optimism over the 1996 Agreement: Dianne Sullivan, the director of trade policy for the National Association of Manufacturers, called the agreement a step forward in establishing better relations with China. See U.S., China Agree on Copyright Shields, supra note 124, at 998.

126. See Trade Report Cites Chinese Progress on Piracy, Hous. Chron., May 1, 1997, Business Section at 2.

127. See U.S.-China Trade Relation (June 17, 1997) (testimony of acting USTR Charlene Barshefsky in House Ways and Means Trade Subcommittee), available in 1997 WL 11233854. The Software Publishers Association announced figures for estimated losses to piracy and found no improvement in China in the last three years. See Seth Faison, Chinese Cracking Down on the Pirating of CD's, N.Y. TIMES, June 24, 1998, at A10. Although U.S. figures vary widely, industry groups estimate that U.S. entertainment and software companies lost between $\$ 500$ million and $\$ 1$ billion in 1998 due to piracy in

China. See Tomlinson, supra note 53, at 6.

128. See Faison, supra note 127, at A10.

129. See U.S.-China Trade Relations, supra note 127.

130. See supra text accompanying notes 103-129.

131. See supra text accompanying notes 36-66. 
when China agreed to increase its protection of U.S. intellectual property. In 1996, however, China retaliated with its own trade sanctions, and the United States withdrew its threats. Since 1996, the United States has not invoked Special 301 against China.

On the other hand, the United States has never threatened trade sanctions against Russia. The United States did place Russia on the Watch List and, later, the Priority Watch List, ${ }^{132}$ but the USTR never elevated Russia to the Priority Foreign Country List and never threatened trade sanctions. There are several possible explanations for the disparate treatment. First, after the collapse of the Soviet Union, the United States became a staunch supporter of President Yeltsin and the Russian government. ${ }^{133}$ The United States feared that Russia would revert to communism if President Yeltsin were perceived as weak or if the economy faltered significantly. Trade sanctions could have precisely these effects. Opponents of President Yeltsin's reforms would use the threatened trade sanctions as evidence of Russia's weak position vis-à-vis the West in their propaganda battles for the hearts and minds of Russian citizens. Trade sanctions would also weaken an already unstable economy. To prevent these undesirable outcomes, the United States opted to tolerate Russian abuses of U.S. intellectual property rights in the short term.

Second, China was a much more significant trading partner than was Russia. In 1998, the United States imported almost $\$ 6$ billion in goods from China and exported more than $\$ 1$ billion in goods. ${ }^{134}$ In the same period, the United States imported one-tenth of that amount of goods from Russia-less than $\$ 500$ million worth-and exported less than $\$ 300$ million worth. ${ }^{135}$ The United States sought to reduce the trade deficit with China by threatening China with denial of access to the U.S. market. The United States also viewed China as a potentially huge market for U.S. goods, and used Special 301 as a tool to open up China's market. Russia, on the other hand, was still a relatively small market and would likely remain so in the short term until the Russian economy was reformed. The United States did not consider trade sanctions as a necessary part of its economic strategy toward Russia.

Third, U.S. reaction toward China was influenced by events in Tiananmen Square and other human rights abuses, as well as China's export of arms and nuclear technology to developing countries. When the United States considered Special 301 action against China in 1991, it was at least somewhat affected by China's negative image in the United States in the aftermath of Tiananmen Square. Additionally, some U.S. leaders viewed negatively China's ballooning trade surplus with the United States, allegations that China forced political

132. Russia remains on the Priority Watch List.

133. President Bush and President Kohl of Germany announced that the United States and Germany and their allies would give Russia \$24 billion in aid. See Joel Kurtzman, Bush's Surprise Plan to Help Yeltsin's Government, N.Y. TIMES, Apr. 5, 1992, §3, at 2.

134. See International Financial Statistics CD-ROM, International Monetary Fund, Wash., D.C. (Nov. 1999).

135. See id. 
prisoners to produce goods for export markets, and reports of China's export of arms and nuclear technology. ${ }^{136}$ Even though Russia also engaged in human rights abuses in its past, the United States appeared willing to forgive past sins of the Soviet state and judge the Russian government anew.

Fourth, the United States sought to maintain good relations with Russia so that the U.S. government could influence Russia's policies of disarmament and nuclear non-proliferation. The United States was concerned that Russia would be tempted to sell off nuclear weapons and knowledge to support its weakened economy. Trade sanctions, by worsening Russia's financial position, could encourage such undesirable behavior.

Finally, unlike Russia, China's piracy efforts were aimed at both its domestic market and export markets. The Business Software Alliance reported that China had the capacity to produce ninety million CDs per year, yet its domestic market could only absorb five million CDs annually. ${ }^{137}$ China actually exported most of its pirated music and software to the West; therefore, its low-cost, pirated works competed directly against legitimate U.S. goods. ${ }^{138}$ Russia, on the other hand, produced its pirated works primarily for domestic consumption, or, at most, for consumption in the former Soviet republics. ${ }^{139}$ Even though the United States disapproved of piracy in Russia, it abhorred China's blatant efforts to pirate works of U.S. producers and then compete directly against those producers.

\section{CONCLUSION}

Even though the development of copyright law in Russia and China is similar in many respects-both developed their copyright laws later than did Western Europe; both refused to adopt international copyright agreements until international pressure mounted; and both refused adequately to protect foreign works-Russia and China experienced very different treatment from the United States when U.S. copyrights were violated. The United States aggressively pursued trade sanctions against China when it failed adequately to protect U.S. intellectual property, while it adopted a comparatively mild approach with Russia. The United States used Special 301 to threaten China with trade

136. See Keith Bradsher, Panel Asks Bush to Cite Three Nations, N.Y. TimES, Apr. 26, 1991, at D1. The 1991 debate over granting most-favored nation status to China was dominated by similar issues: human rights, including oppression in Tibet and the trials of dissidents; Beijing's soaring trade surplus with the United States, with Chinese exports booming at the same time that imports were restricted; the export of products made by Chinese prisoners who are paid little or nothing for their work; and accusations that Beijing is secretly selling weapons and nuclear technology to Algeria, Pakistan, and other developing countries. See Nicholas D. Kristof, Chinese Ties: Frosty to Icy, N.Y. TIMES, May 2, 1991, at A13.

137. See Smith, U.S. Trade Officials Plan to Fault China, supra note 120, at A10.

138. See id.

139. At least some of the pirated works shipped to the former Soviet republics eventually entered Western markets. See Almar Latour, Russian Lawyer Cracks Down on Piracy, WALl ST. J., June 9, 1997, at 13B. 
sanctions but has never pursued such remedies against Russia. There are several reasons for the past disparate treatment.

The United States pursued different political, economic, and military goals in its relationships with Russia and China. First, the United States supported President Yeltsin and the Russian government after the collapse of the Soviet Union and sought to strengthen the Russian economy, not to undermine it with threats of trade sanctions. Second, the United States sought to reduce its trade imbalance with China through threatened trade sanctions. Third, Tiananmen Square and other human rights abuses by China influenced U.S. policy toward China. Fourth, the United States sought to maintain good relations with Russia to influence its policies of disarmament and nuclear non-proliferation. Finally, the United States more aggressively attacked piracy in China because China exported its pirated works into Western markets, where the low-cost, pirated works competed directly against legitimate U.S. works. For all of these reasons, the United States has pursued China's copyright abuses more aggressively than it has pursued similar abuses by Russia.

In the immediate future, the United States remains unlikely to invoke Special 301 against Russia for the reasons mentioned herein. Similarly, the United States is unlikely to invoke Special 301 against China, given the importance of U.S.-China relations and the United States' most recent failure at threatening sanctions in 1996. As China becomes a greater economic power, able effectively to wield trade weapons against its economic opponents, the United States must consider other avenues for relief from piracy and other violations of intellectual property laws. Perhaps China's accession to the World Trade Organization will provide the relief the United States seeks. On the contrary, when Russia stabilizes its economic and political systems, the United States may consider invoking Special 301 and threatening trade sanctions to force Russia to provide greater protection for U.S. intellectual property. 